Vol. 7, No. 2, 2020

https://doi.org/10.23939/eem2020.02.078

UDC 330.8(4/9):657.421.32

JEL Clasification Code M41, B15, N01

O. Lemishovska

Lviv Polytechnic National University, Ukraine, $\mathrm{PhD}$, Associate Professor

E-mail: leslem@ukr.net

ORCID ID: 0000-0002-5695-0924

\title{
INTANGIBLE VALUES IN THE ACCOUNTING THEORETICAL AND APPLIED SPHERE OF THE EASTERN GALICIA OF THE SECOND HALF OF XIX - THE BEGINNING OF XX CENTURY: HISTORICAL DISCOURSE
}

\begin{abstract}
The evolution of the economic category "intangible value of the enterprise" and the content of the objects that present it are summarized. The historical formalization of intangible components of the value of the enterprise is given and the development of accounting methodology and methods of reflection of objects related to the concept of "intangible asset" is analyzed. The article presents theoretical and applied aspects of the reflection of intangible assets by accounting in the global and regional sections. The first part of the study highlights the generalized and systematized by the author historiography of the basic principles of accounting for intangible assets with an emphasis on existing problem aspects and ways to solve them at the turn of the century. The second part of this historical and accounting investigation reveals the panorama of solving the problem of accounting for intangible assets in Eastern Galicia. The study of this component has the character of theoretical scientific knowledge and is based on literary criticism, based on selected textbooks and scientific works of accountants of the study area.
\end{abstract}

The hypothesis of the study is the assumption of the development of Western Ukrainian scientists in the period declared by the article of certain ideas that can be rationally used to develop modern concepts of accounting for intangible assets. Among the scientific novelty of the article is a proposal on the principles and approaches to writing off the value of intangible assets, as well as methods of accounting for goodwill in the accounting method, substantiated in the past. The study is based on historical-retrospective analysis, and therefore the main methods of historiographic analysis and historicalgenetic method were used.
Key words: intangible asset, enterprise reputation, goodwill, methodology of accouting, Scientific knowledge, Galicia territory

\section{Introduction}

The reflection in accounting and the presentation in one way or another of public information about economic resources of the intangible type during the evolution of this system have always been and remain the subject of discussion. The dual economic and legal nature (as a special institution and economic resource) gives rise in accounting practice to different approaches to accounting for the intangible value of the enterprise. Throughout the history of the theory of accounting and practical accounting, no unified approaches to the recognition, evaluation and agreed methods of reflection of the accounting system of many objects of intangible type. This type of resources has a dual economic nature - they form a value comparable only to a particular enterprise (for example, a trademark or trademark) and, at the same time, the total capital of owners, expressed through their value. However, a significant part of these objects cannot be identified using traditional accounting tools. This makes it insurmountable to establish the share of the value of the business when one of the partners leaves.

Accounting is influenced by changing financial and economic doctrines, and therefore, during the evolution of this system, it has acquired a different conceptual framework for intangible assets. In the vast majority of economic theories, 
the content of this category was reduced to the fact that the intangible component of the value of the enterprise organically combines all the assets of an intangible nature available at the enterprise. The dominance of certain financial and economic doctrines in a particular period of time caused the fact that intangible objects were expressed in different accounting categories. At various stages, the terms "intangible assets", "intangible assets", "intangible capital", "goodwill" were used in relation to them, and later - "information and intellectual assets", "intellectual capital" and others. Regardless of the terminological content, the basic basis for all concepts is the understanding of the ability of intangible assets to provide benefits in the future, significantly affect the market value of the enterprise and act as the main resource of its competitive advantages.

The basic principles of accounting have been built and continue to be based on the following principles: write-off of internally generated assets simultaneously with the capitalization of functionally identical acquired intangible assets and their amortization (write-off). The lack of sound financial and economic doctrines for the assessment and establishment of agreed recognition criteria, negatively affects the ability to develop objective accounting methods, which, in turn, complicates the problem of managing them at the enterprise level, operating this information in capital and investment markets.

In economic theories (paradigms), intangible economic resources in the synthesized expression are represented through goodwill or intellectual capital, the structure of which in turn is formed by human, structural and consumer (client) capital. Similar to the "blurred" financial and economic concepts is the modern standardization of accounting, which has the ability to reflect different groups of intangible assets on the basis of expert judgments. The problem intensified with the introduction of the ideology of positivism in the theoretical and applied economy in the 1990s, which had a significant impact on the development of financial models of decision-making, including the use of accounting and reporting information. Based on expert assessments of information and intellectual capital, the efficient market hypothesis (Efficient Market Hypothesis) and the Capital Asset Pricing model were built. In these models, data on intangible economic resources are generated on the basis of subjective estimates, which are said to provide a fairly reliable expression of the fair value of assets and liabilities [1]. However, in modern accounting standardization, as the well-known scientist Baruch L. concludes, "many estimates, such as the fair value of non-trading (non-market) assets, and especially goodwill, are often not better than simple assumptions and tend to manipulate... indiscriminate write-offs of intangible assets. costs significantly deprived the profits of their ability to inform about the results of the enterprise and forecasting" [2].

In the process of scientific knowledge of the general theoretical principles of accounting or individual issues of intangible assets of the enterprise often indicate the feasibility of turning to the developments of the past, in which you can find original ideas relevant to the present. It is believed that the use of certain provisions of past developments can provide identification of new opportunities and ways to generate information about the intangible potential of the enterprise. For example, domestic scholars $\mathrm{M}$. Koryagin and $\mathrm{P}$. Kutsyk argue the expediency of turning to the development of the German school of accounting, which conducted research on the use of fair market valuation in accounting in the late nineteenth century and which were not fully implemented in the twentieth century [3, p. 10]. During the period under study, theoretical developments in the field of accounting and organization of accounting practice in Austria-Hungary, including Eastern Galicia were part of German accounting, which justifies the direction of our study, updating assumptions about making some successful decisions directly by scientists.

\section{Methodological approach}

To ensure the study of the evolution of theoretical accounting knowledge about intangible assets, methods and approaches to their reflection in practical accounting, providing information on the value of intangible capital in accounting, a triad of approaches: empirical (evolutionary experience of reflecting objects of this type in practical accounting); normative-practical interaction of regulatory requirements and theoretical progress of financial-economic and accounting knowledge for the formation of information about the intangible potential (capital) of the enterprise (fundamental): the level of in-depth understanding and expression 


\section{O. Lemishovska}

in terms of the essence of accounting developments of scientists, ie science. object "intangible assets" allowed to identify the conceptual and substantive content of articulated objects (business reputation, goodwill, intellectual capital, etc.) and the direction of developing a methodological arsenal of accountants in Eastern Galicia. The study is based on retrospective analysis using historiographical and historical-genetic methods.

\section{Formulation of the problem}

The purpose of the article is to reveal the evolution of the concept of "intangible assets" as an accounting and economic category and to study the historical development of approaches to the reflection of these objects by the accounting system. The defined goal is focused on the retrospective analysis of specifically selected works of East Galician scientists in the field of accounting for intangible objects, analytical assessment of their proposed conceptual and methodological approaches in terms of the period and present. The analysis of the obtained results is aimed at formulating recommendations on the possibilities of using some successful ideas of the past in modern research.

\section{Analysis of recent research and publications}

In its specialized report for 2019. "Eccountancy Europe indicates that current accounting methods in many cases do not take into account internally generated intangible assets, which have become a major component of companies' market value" [4, p. 4]. Assessing the possibility of developing accounting techniques based on existing standardization, a well-known researcher in the field of intellectual capital Magg W. concludes that the search for "an objective approach to the valuation of intangible assets creates huge problems, and for this reason the formation of objective accounting for intangible assets is either quite difficult or almost impossible" [5, p. 172].

Modern case studies use various ascending positions to improve the accounting of intangible assets, but also offers a reference to the achievements of the past. This applies both to the view of the content of economic matter of certain types of economic resources, and the evolution of accounting techniques in general. For example, IM Nazarenko argues that "for an in-depth understanding of the accounting interpretation of the studied category is important retrospective analysis of the development of categorical-conceptual apparatus" [6, p. 135]. Circumstances of origin and evolutionary changes of the accounting category "intangible assets" are considered important for modern research by scientists. For example, based on the results of a comprehensive case study, VS Rzhanitsyn concludes that this aspect "is of great interest because the analysis of the historical preconditions for the reflection of intangible assets and existing standards will allow to formulate a description for the modern accounting category" [7, p. 10].

Regarding the methods of reflecting the entire intangible potential of the enterprise, expressed by the category of goodwill, a similar position is taken by SV Kucher: company value ", is relevant" [8, p. 1165].

An example of the use of some developments of the past is the results obtained in the works of I. Yaremko. Based on the developments of Western Ukrainian scientists of the period under study, he formulated and introduced into scientific circulation the accounting category "Ideal Capital", which synthesized the productive power of all intangible economic resources of modern enterprise. His work [9] and copyright [10] substantiate the impossibility of expressing information and intellectual economic resources in the traditional way (from assets to capital), ie on the basis of pre-estimated values of a special kind that form the price of the firm. This development proposes a new approach (from capital to assets), ie the ascending disposition is the assessment of the information-intellectual component of the total capital of the enterprise ("ideal capital"), and its productive function is expressed in terms of "ideal resources", offering its own, but taking into account the developments of Galician scientists of the past, improved balance sheet format for modern corporations through the additional introduction of articles "Intellectual assets" on the active side of the balance sheet and "Intellectual Capital" in the liabilities of the balance sheet. It is substantiated that such a basic basis "allows a more comprehensive representation of the intangible (information-intellectual) component of the potential of the corporation" [11]. 
The main materials. Historiography of the problem

Various concepts in relation to the intangible economic resource (intangible value) of the enterprise in the commercial sense has long been used and in a generalized sense is reduced to the acquired business reputation of the enterprise. The importance of the reputation component for the effective functioning of the enterprise over a long historical period necessitates the quantitative measurement of this category to operate it in the applied economy. The accounting system is the only economic tool that can formally (according to an agreed method) to establish the value of intangible assets of the enterprise. However, for the entire historical period there is a difficulty in providing this function by the accounting system, which in general terms is that the economic value of the intangible asset taken on the balance sheet in the current period is determined by the amount of income they expect to receive from it in the future.

From the time of formation of accounting as a formalized system (science) to the middle of the $\mathrm{XX}$ century. in the accounting field was dominated by normative theorizing with a pronounced mainstream application of the deductive method. Theoretical constructions of the then accounting system for accounting and reflection of information in accounting were largely based on prescriptive nature (content of mandatory instructions), and the improvement of accounting for intangible assets was based on the opinion of an individual researcher and for a specific situation. This was especially true of objects such as trademark, brand, trademark, business reputation, and so on. Formed in any historical period, the theoretical structure of accounting is in the coordinates of decision theory, measurement theory (evaluation) and information theory, where there is a clear problem with intangible assets. Information about the intangible potential of the enterprise is especially important for investment decisions, and therefore due to the lack of clear formalization of data on these objects, decision-makers are dominated by hermeneutics (summary method of interpretation), ie arbitrary interpretation and interpretation of these indicators.

During the study period in Europe and also in Eastern Galicia, the predominant position of scholars was that various intangible assets are the values of fixed assets and represent the real value of the company's capital. In accounting historiography on the subject, it is believed that one of the first established references to "incorporeal intangible assets" with an emphasis on their reflection in accounting were contained in the book R.P. Coffy "Tableau synoptique des principles gene raux", published in Paris in 1832. The earliest established definition of goodwill as a definitive concept is given in the "British Dictionary" ("A Counting House Dictionary") in 1883[12]. In it, goodwill is disclosed (interpreted) as an advantage associated with a good reputation (well-established business). Goodwill is said to have value because a business acquired at an "inflated" price is expected to bring in excess profits. In the future, goodwill is associated with its elements (brand names, patents, trademarks, copyrights).

In a more formalized accounting sense, the term "intangible assets" was used in 1916 in the article "Intangible assets in the balance sheet", published in the "Journal of accountancy" [13]. In the period declared by our article, with varying degrees of formalization, the category of "intangible assets" contained four types of assets: goodwill, patents, trademarks and copyrights, which were combined on the basis of lack of material form. The intellectual capital market formed during this period required formalized information, ie the need to reflect intangible assets in the company's financial statements. This has led to increased attention of scientists to develop satisfied methods for the accounting system.

In accounting historiography, L. R. Dicksee is recognized as a well-known scholar in the field of accounting for intangible assets. It is believed that he published in the economic journal The Accountant in 1897. article (lecture) "Goodwill and its Treatment in Accounts" [14] and published in 1906. the manual laid down certain basic provisions for the formalization of this accounting object [15]. According to this scholar, "goodwill as an asset includes the benefits that a business owner receives where the value of the business depends on business relationships - goodwill acquired in the acquisition of a business consists of the right to use those relationships". In other words, the elements of business relations were emphasized in these works - clients will continue to increase cooperation with the company. In his works, the author considers in detail the issue of valuation of goodwill and the order of its reflection on the accounts. Note a separate of the rarely proposed 


\section{O. Lemishovska}

approaches - write off goodwill from the balance sheet as quickly as possible at the expense of reserves, not profits [15] (italics highlighted by the author of this article).

Among the scholars who studied the problem of accounting for goodwill was a practicing accountant and founder of the London firm of chartered accountants Leake P. D. In 1914. he published the article "Goodwill, its nature and evaluation" and published in 1921. the book "Commercial goodwill: its history, value and treatment in accounts" [16]. Goodwill was seen as a collection of intangible assets: patent law, copyright and the right to conduct business, taking into account the use of brand names and trademarks. It was believed that the total working energy of these assets provides additional income in the future. In his proposed principles of construction of the valuation methodology, the postulate was put forward - the current market value of the business is associated with the criterion of future (expected) benefit. In this work was formulated "Super-profit Valuation Theory of Goodwill". Goodwill is seen as a right formed on the basis of past resources expended for the expected profit (increase in the value of the company). The cost of goodwill in this sense depends on the probability of earning future profits. The described theory became, in fact, the basis for the formation of a profitable method of estimating goodwill.

Another scholar who studied the problems of accounting for goodwill was Hatfield HR, who in his work "Modern Accounting, its principles and some of its problems" [17] argued the impossibility of objectively assessing goodwill and took the position that in the financial statements of this object should be reflected subject to its purchase for the amount paid. Many scholars have criticized the approach to goodwill valuation based on expected superprofits, one of which was Kaner H. A. His New Theory of Goodwill [18] stated that superprofit is a variable and the theory of goodwill valuation based on it is incorrect. These arguments have given a new impetus to the study of accounting for intangible assets.

Closer to the middle of the twentieth century. in the conditions of capitalist industry the role of a trademark ("trademark", a trademark) as an effective means of advertising, a means of increasing sales, increased. The first legislative (civil law) norms appear, guaranteeing the protection of trademarks, which within different countries had different variational approaches. The value of a trademark (trademark rights) as an intangible asset consists of the cost of its development (acquisition) and payment of state duty. A significant impetus for the development of the international system of intellectual property protection was made by the development of the Paris Convention (1883), which concluded the International Agreement (Convention) on the Protection of Industrial Property, which allowed to protect the rights of patent holders in different countries.

In 1944, the Accounting Procedures Committee of the American Institute of Accountants issued the world's first normative document - Accounting Research Bulletin № 24 “Accounting for Intangible Assets" [19]. It substantiates the nature of intangible assets and discloses the rules relating to the recognition, measurement and order of their accounting. The defining feature of this document was the division of all intangible assets into objects with a certain useful life (patents, copyrights, licenses, franchises) and objects with an indefinite term (trademarks, trade secrets, perpetual franchises, subscriptions and organizational costs). For both types of intangible assets, a cost estimate was used.

Analyzing the research of accounting scientists of the late nineteenth century - early twentieth century, we can conclude that in this period formed two approaches to accounting for intangible assets or goodwill - in terms of current market value (future profits) and in terms of historical value (the difference between the acquisition cost and the book value). Approaches to the direct reflection in the accounting of such objects were divided into: 1) capitalization of acquired intangible objects or goodwill in the balance sheet; 2) write-off of the value of purchased objects by their depreciation; 3) writeoff of purchased goodwill for expenses or due to capital reduction.

\section{Accounting for intangible assets in the territorial context}

Accounting category of the intangible component of the value of the enterprise in the late nineteenth century. both in the world and in the study area remained insufficiently studied. In the 
then (traditional) model of accounting, the dominant input factor was physical capital (tangible assets). However, the practice of doing business, which has developed dynamically both in Europe and in the study area, required a more extensive reflection in accounting (especially in the financial statements) of intangible factors that are actually owned by the company. On the territory of Eastern Galicia there were companies with wellknown brands: Concern of French oil industrial and trade companies "Malopolska" ("Malopolska", Concern francuskich towarzystw naftowych, przemyslowych i handlowych we Lwowie); PolishItalian Joint Stock Company of the Oil Industry "Bonariwa" (Polsko-wloska spylka akcijna dla przemyslu naftowego "Bonariwa" we Lwowie), Dutch Oil Syndicate. Limited Liability Company Holenderskyj syndykat naftowy. Limited Liability Company in Lviv). This further exacerbated the need to reflect the intangible component of enterprises in their financial statements. Numerous financial and economic paradigms have emerged, emphasizing the importance and necessity of accounting information for intangible assets for business management.

At the forefront of economists and accountants of the region, who had sufficient opportunities to implement regional developments, raised the question of formalizing the very concept of intangible value of the enterprise. In their work, East Galician accountants emphasized that "capital should be understood as a set of all values that ensure the activities of the enterprise" [ 20 p. 5.]; capital is the establishment of the height of the value of the economy in monetary units through the assessment of material and ideal values, which discourages the company [21] (italics highlighted by the author of this article).

Regional economic theories (paradigms) have formulated various variations on the semantic disclosure of data on intangible objects. For example, let's look at the capital of the famous Austrian economist Shumpeter IA, who at that time worked in Western Ukraine (Chernivtsi University): "the concept of" capital "is money in essence and means either real money or some goods valued in money" [22 ] (italics highlighted by the author of this article). We emphasize that this scientist with high professional authority in Galicia and the entire Austro-Hungarian state recognized the full component of the capital of the enterprise economic resources of the intangible type. In parallel, we present the view of regional scholars in the field of accounting regarding the reflection of accounting intangible component (ideal values) of the enterprise: "from the point of view of national economy [23, p. 171]. This approach was put forward for the first time (1910) in world accounting research.

At the national level, the problem of accounting for such intangible components of fixed assets as patents, organizational funds (costs of establishing a business), the formation of clientele and other similar values were considered against the background of the German school of accounting, which included scientists from AustriaHungary. In Eastern Galicia, the "authoritative" and widely used in our field of theoretical knowledge was "Buchhaltungs-Lexikon" Stern R. (1902) [24], works by Reisch R., Kreibig J. Bilanzund Steuer $(1907 ; 1909)$ [25], as well as "Di Bilalanzen der Uftigenfellitaften" by Simon G. (1899) [26]. The works of Staub also had a sufficient influence on the progress of accounting (theory, practice, professional training) [27] and Sher [28].

Herman Veit Simon, based on the provisions of the German Commercial Code in 1861. published a work of the monographic type, which in the form of the following edition was widespread and authoritative among Galician scholars [26]. The general conceptual content of his works on the accounting of intangible assets was based on jurisprudence: "by means of acquisition (payment - transfer of ownership) such economic property confirms its ability to circulate and, consequently, acquires the right to include it in the balance sheet" [26, c. 169]. However, H. Simon emphasizes that "are not property and are not reflected in the reporting of items that can not be unambiguously assessed, such as the image and know-how of the organization, the quality of staff or relationships with contractors". We find a critique of this in Staub before the VII edition of the commentaries on the German collection of commercial laws (p. 797): "It seems that H. Simon was too captive to double-entry bookkeeping and in terms of conjuncture (dominance of legal aspects over economic) seeks to explain joint-stock balances". Nevertheless, Staub consciously or opportunistically supports this view: "the balance sheet of a joint-stock company is not a property 


\section{O. Lemishovska}

balance sheet, but a distribution balance sheet, which allows us to see what value the company has for distribution and how large the contribution to this value of an individual partner is" [27, p. 796].

In some works of East Galician accountants it was considered (mostly on a declarative rather than methodological level) that accounting should take into account both "objects of material nature and values of intangible nature" (intangible benefits) - the relationship (clientele of a merchant or lawyer) and the rights that use (privileges, real rights, etc.) " [30; 31; 32; 23, p. 1-2]. At that time, a fairly large content of various intangible assets was synthesized in the concept of "organizational funds", ie the cost of organizing the enterprise and its subsequent acquisition of market value (prototype of the category "goodwill"). It is around this issue that perhaps the largest discussions have taken place. There were various arguments and approaches to reflect their asset or justification for the need to write off in one way or another.

In the works of Reisch R., Kreibig J. such organizational funds were considered as "intangible value (ideal asset) and real asset to the extent that the funds spent can be reimbursed in the liquidation of the enterprise through payment by a third person" [25, II , p. 91 ]. Staub pointed out: "In addition to real things, the asset can also reflect all the objects that are the subject of the progress of the law, as well as such economic values as unprotected trade secrets, company law, etc. These things constantly form part of the asset, but according to the law (jurisprudence), their accounting is verified only when the necessary costs were incurred for their acquisition" [27]. That is why in the field of accounting such an article was not considered fundamentally incorrect (unrealistic), but only as one that "contradicts legal norms and trade customs, and therefore incorrect" [29; 31; 25, II p. 16].

Austrian legislation at the time forbade the capitalization of almost all types of intangible assets, as well as the costs of establishment and to reflect them in the balance sheet. However, under the influence of the needs of practice, the work of Cher I. F. [28] and some European (primarily French) developments in the theoretical developments of East Galician accountants began to dominate the position that although such amounts in principle burden the main balance sheet of the company, but in terms of reflecting potential energy should be introduced into the "balancing system", as the company has benefited from the funds spent in subsequent years. Therefore, at the end of the XIX century the accountants of the region begin to have the first attempts to solve the problems of accounting for intangible assets of the enterprise by means of theoretical developments, which, however, were fragmentary and were solved in the general system of accounting improvement.

The authors, with a few exceptions, used the traditional positivist approach of the time, which provided for the development of accounting theory based on the description of the existing practice at that time, including and foreign companies operating in the region (for example, above). For theoretical developments in the field of accounting of intangible assets of great importance were the state legislation on the conceptual and categorical apparatus, as well as instructive provisions for the reflection of accounting values of intangible nature. In many cases, regional accounting specialists were involved in the development of mandatory rules and accounting regulations. Therefore, in the theoretical accounting developments of East Galician accountants, there are numerous appeals and references to the legislation of the AustroHungarian state and, for comparison, similar legislation of other countries.

First of all, in our opinion, it is important to single out the legislative consolidation of the conceptual apparatus in relation to the categories of "capital", because it is from these ascending positions that the preconditions for developing methods of "capitalization" on the balance of intangible values followed. So, for example, the Austrian shareholder instruction ( $\$ 28$, item 6) under the fixed capital it is a question of all share capital, that is the cost of the enterprise is equated to a market estimation. At the same time, according to Article 18 of the Implementing Instructions to the Austrian Personal Tax Act of 25 October 1896, applied capital is not only all types of "classical" investment in entrepreneurship (acquisition of tangible assets), but also and the funds associated with the attraction (attraction) of foreign capital (the cost of printing and advertising, quotations). In a generalized form, this law refers to fixed 
Intangible values in the accounting theoretical and applied sphere of the Eastern Galicia of the second...

capital as capital invested for a long time in entrepreneurship. However, certain paragraphs of this law ( $\$ 92$ and $\S 94)$ operate in one case with the concept of "applied", in another "invested" and at the end of "fixed" capital. Unambiguous interpretation of the disposition of intangible values in these terms is extremely difficult. The only thing that is clear from the imperative prescriptions is that in relation to assets of intangible nature the position is held that when an enterprise uses this type of economic resources, their energy is converted into working energy of capital, ie it acquires the power of capital.

Due to the content of legal interpretations, the difficulty on the basis of evidence to express intangible objects, in accounting practice, such data were used to a limited extent. However, in the educational process of training accountants, questions were introduced regarding the recognition, valuation and ability to reflect intangible assets in the accounts as a component of the property assets of the enterprise.

Based on this, accountants of the region formulated approaches to the accounting of intangible assets. For example, we give the content of topics from the textbook for the Higher Agricultural School in Dublin Au Juliusz (1889) [29]. This textbook had a scientific and theoretical orientation and the nature of optional use; it was published with the financial support of students (wydane nakladem b. studentów b. wyższej szkoly rolniczej w Źabikowie i wyższej szkoly rolniczej w Dublanach) "Nauka rachunkowosci dla potrzeb cospodarstwa wiejskiego zastosowanej".

Table 1

\section{Contents of the manual topics "Nauka rachunkowosci dla potrzeb cospodarstwa wiejskiego zastosowanej", relating to intangible assets}

\begin{tabular}{|l|l|}
\hline \multicolumn{1}{|c|}{ Contents of topics (in the original language) } & \multicolumn{1}{c|}{ Contents of topics } \\
\hline 1. Części składowe majątku & 1. Components of property wealth \\
\hline $\begin{array}{l}\text { 2. Szacowanie czyli oznaczenie wartości części } \\
\text { składowych majątku }\end{array}$ & $\begin{array}{l}\text { 2. Valuation or marking of the value of property } \\
\text { components }\end{array}$ \\
\hline 3. Pogląd krytyczny na błędne sposoby szacowania & 3. A critical look at the wrong assessment methods \\
\hline 4. Zestawienie inwentarza & 4. Inventory list of components of property assets \\
\hline $\begin{array}{l}\text { - Rachunki formalne: rach. bilansu, rach. kapitału, rach. } \\
\text { zysków i strat }\end{array}$ & $\begin{array}{l}\text { - Formal accounts: balance sheet account, capital accounts, } \\
\text { profit and loss account }\end{array}$ \\
\hline - Rachunki rzeczowe: rach. części składowych majątku & $\begin{array}{l}\text { - Property accounts: accounts of components of property } \\
\text { wealth }\end{array}$ \\
\hline
\end{tabular}

The material on the above topics was undoubtedly directed to tangible objects, and the emphasis on intangible property was an important component of this textbook. Assessment of property, including intangible assets, is presented from the point of view of the author of the manual. This approach is presented to the inventory of property, as well as its reflection on property accounts and capital accounts.

The above-mentioned Austrian law of 1906, analogous to $\$ 261$ of the German Code of Commercial Laws, categorically stated: "funds for the establishment and management of entrepreneurship should not be included in the balance sheet as an asset". Instead of the asset item, it was supposed to use the item "losses", which in the balance sheet of that time was reflected on its active side.

The comparative content of the imperative prescriptions of the two states is aimed at comparing the positions of German and East Galician accountants regarding the basic approaches to the methodology of accounting for this type of costs. For example, in the works [24; 25; 28] German accountants proceeded from the position that the costs of the organization that are not reimbursed for the reporting period are, in fact, losses (specific losses of an economic nature). Given this "specificity", they consider them in terms of "anticipation" (action that precedes the onset of 


\section{O. Lemishovska}

real events), proposing to use a separate "account of losses of organizational funds" [25, II, p. 120]. That is, in fact it was a reflection in the balance sheet (asset) of a kind of loss account (loss). In this context, some scholars of the region expressed a slightly different view on the existing issues: "It is absolutely true that loss is not a value and cannot be presented as a value, but organizational funds, when they have an exchange value, are an ideal fixed asset and should be reflected on the basis of this content of this economic category" It was proposed - "if the law wants to limit the distribution of profits, it is much more logical and correct to direct the relevant part of the profits to reserve capital" [23, p. 172].

However, there was no unanimity among East Galician accountants on this issue, and therefore various discussions were held. There has been controversy that "organizational funds" (in the modern sense of "internally formed goodwill" or "business reputation") may not have any exchange value at all and therefore it is debatable to reflect them as property (intangible asset) [30; 32]. In contrast, other considerations were put forward - when establishing a business, the owner usually transfers cash or items equivalent to this cash payment, which were articulated as "Apport" (intangible assets, from the French). It was noted that "French accounting still recognizes the rights, patents, founding funds as actif fictif, ie as the estimated value, although, in contrast to actif reel, uses very limited approaches to their introduction into the accounting system $[23 ; 30 ; 31]$.

Some scholars have emphasized the debatable reflection in the balance sheet of such an active article, based on the fact that the accounting expression of the emergence of such value should guarantee its existence as property at the time of sale of the business. Such intangible assets were proposed to be called unfinished (unfinished and "hanging in the air") property, and the capital that concerns it - unfinished capital, ie it was, in fact, the balance sheet item "deferred expenses" [23; 30].

The problem was the reflection of unsold shares (assets), as well as their sale at a rate above par (liabilities). The norms of the Austrian trade instructions (§53) of 20.09.1899 prescribe that "the amount of increase (growth) of fixed capital due to the sale of shares at a higher rate than the nominal value should be treated by the reserve fund". This legal norm "automatically" obliged the accounting department not to reflect the increase in the value of capital (liabilities), but in connection with the presentation of the received funds (assets) to show capital reserves. In practical accounting, this is how the issue of presenting the growth of shares in property and capital accounts was resolved, bypassing the balancing item "internally generated goodwill".

Some studies by East Galician accountants suggested that some types of intangible assets have the ability to increase their value without additional costs, which should be reflected in accounting not only at the time of sale, but also at the end of the year directly in the balance sheet. From this point of view, it has been suggested that "the increase in values such as the increase in property and at the same time the increase in capital should be recorded at the end of the year, although we usually do not see growth, just as we do not see growth of grass" [23, p. 31]. It was proposed to measure the growth of the value of intangible assets through an inventory organized directly at the enterprise. The period of the late XIX - early XX centuries. characterized by rapid economic development of the region. The scale of development of the worldfamous Boryslav oil basin, salt mines, as well as the construction of railways and related economic activities have led to the emergence of numerous foreign joint-stock companies in the region. Financial and credit institutions (unions) of the non-state type, large-scale insurance organizations were created. In practice, the operation of the concept of "enterprise value" has become particularly important, which gave a new impetus to accounting developments in the field of accounting and reflection in the reports of enterprises of their intangible property.

Here is a meaningful presentation of individual topics (issues) related to the accounting of intangible components and their reflection in the financial statements. The works of Sciborski A. and Ciompa P. are chosen as examples. 
Intangible values in the accounting theoretical and applied sphere of the Eastern Galicia of the second...

\section{Contents of topics that covered intangible assets in manuals $[23 ; 30]$}

\begin{tabular}{|c|c|}
\hline $\begin{array}{l}\text { Sciborski A. Podręcznik do nauki rachunkowości } \\
\text { ogólnej i państwowej (1912) }\end{array}$ & $\begin{array}{l}\text { Ciompa P. Grundrisse einer öekonometrie und } \\
\text { natürliche theorie der buchhaltung (1910) }\end{array}$ \\
\hline \multicolumn{2}{|c|}{ Contents of topics } \\
\hline $\begin{array}{l}\text { Znaczenie s podział majątku w gospodarstwach (the } \\
\text { importance of division of property in farms) }\end{array}$ & $\begin{array}{l}\text { Die Darstellung des Tauschwertes: Vermögen und } \\
\text { Kapital (Representation of exchange value: property } \\
\text { and capital) }\end{array}$ \\
\hline O kapitale w ogóle (about capital in general) & $\begin{array}{l}\text { - Das Verhältnis des Vermögens zum Kapital (the ratio } \\
\text { of assets to capital) }\end{array}$ \\
\hline $\begin{array}{l}\text { Zmiany majątkowe, spowodowane przychodami (changes } \\
\text { in ownership caused by income) }\end{array}$ & $\begin{array}{l}\text { Die wirtschaftlichen Handlungen: } \\
\text { Die Wertveränderungen des Vermögens und Kapitals } \\
\text { (economic action: change in the value of assets and } \\
\text { capital) }\end{array}$ \\
\hline Rozpoznanie majątku (recognition of property) & \multirow{2}{*}{$\begin{array}{l}\text { Gruppierung des Vermögens und Kapitals (grouping } \\
\text { of assets and capital) }\end{array}$} \\
\hline $\begin{array}{l}\text { Oznaczenie ilości majątku (designation of } \\
\text { components of property status): }\end{array}$ & \\
\hline - Majątku czynnego (active property) & \multirow{2}{*}{$\begin{array}{l}\text { - Betriebsvermögen und Betriebskapital (business assets } \\
\text { and working capital) }\end{array}$} \\
\hline - Majątku biernego (passive property) & \\
\hline $\begin{array}{c}\text { Oznaczenie właściwości majątku (marking of } \\
\text { property assets) }\end{array}$ & $\begin{array}{l}\text { - Anlagevermögen und Anlagekapital (fixed assets } \\
\text { and fixed (invested) capital) }\end{array}$ \\
\hline $\begin{array}{l}\text { Oznaczenie i opisanie pojedynczych części składowych } \\
\text { majątku (designation and description of individual } \\
\text { components of the property) }\end{array}$ & \multirow[t]{2}{*}{$\begin{array}{l}\text { a) Verbrauchsvermögen, schwimmendes Vermögen und } \\
\text { schwimmendes Kapital (expendable assets, floating } \\
\text { assets and working capital) }\end{array}$} \\
\hline Oszacowanie majątku (asset valuation) & \\
\hline Zmiany majątkowe (changes in ownership) & \multirow{2}{*}{$\begin{array}{l}\text { b) Ideales Anlagevermögen und Kapital (ideal } \\
\text { (intangible) fixed assets and capital): Schwebendes } \\
\text { Vermögen (floating assets) }\end{array}$} \\
\hline $\begin{array}{l}\text { O zapisywaniu zmian zaszlych } w \text { stanie majątku } \mathrm{i} \\
\text { prowadzeniu w tun celu rachunków (about records of }\end{array}$ & \\
\hline $\begin{array}{l}\text { changes in the state of the estate and holding accounts } \\
\text { on accounts) }\end{array}$ & $\begin{array}{l}\text { Die Akkommodation des Vermögens und Kapitals } \\
\text { (placement of wealth and capital) }\end{array}$ \\
\hline \multirow{3}{*}{$\begin{array}{l}\text { O pozycjach statycznych czyli idealnych (kompensacja, } \\
\text { nowacka, cesia i asygnacja) (About static or ideal positions } \\
\text { (compensation, novation, assignment and assignment)) }\end{array}$} & Preisgewinn mit Vorrat (price increase with shares) \\
\hline & Die Vermögenskonten (asset accounts) \\
\hline & \multirow{2}{*}{$\begin{array}{l}\text { Die Personenkonten: debitorenkonten (personal } \\
\text { accounts: customer accounts) }\end{array}$} \\
\hline \multirow{2}{*}{$\begin{array}{l}\text { Powiększenie i pomniejszenie należytości (increase and } \\
\text { decrease in the scale of ownership) }\end{array}$} & \\
\hline & Eigene Kapitalkonten (equity accounts) \\
\hline $\begin{array}{l}\text { Wplywy ubytków należylości na stan majątku (the } \\
\text { impact of losses on receivables on the state of assets) }\end{array}$ & $\begin{array}{c}\text { Grundsätze der Bewertung in der Bilanz (principles } \\
\text { of valuation in the balance sheet) }\end{array}$ \\
\hline Bilans majątkowy (property balance) & \multirow{2}{*}{$\begin{array}{llll}\text { Bewertung des } & \text { Betriebsvermögens } & \text { (valuation of } \\
\text { business assets) } & & & \end{array}$} \\
\hline Sposód sporządzania bilansu majątkowego (method of & \\
\hline preparing the property balance) & \multirow{2}{*}{$\begin{array}{l}\text { Kritik der gesetzlichen Vorschriften (criticism of legal } \\
\text { regulation) }\end{array}$} \\
\hline $\begin{array}{l}\text { Wzór dilansu majątkowego (property distribution } \\
\text { template) }\end{array}$ & \\
\hline $\begin{array}{l}\text { Oddanie i przechowanie majątku (Return and } \\
\text { preservation of property) }\end{array}$ & $\begin{array}{l}\text { Bewertung des idealen Anlagevermögens (valuation of } \\
\text { ideal assets) }\end{array}$ \\
\hline
\end{tabular}

The textbook Sciborski [30] and the theoretical development of Ciompa P. [32] had different character and content. The first directed accounting as a general and social science and was intended for the educational process in Lviv institutions of the university type and was based on 


\section{O. Lemishovska}

the data of practical management (opracowany wedlug wykladów radcy Dworu Tadeusza KlusikOrzechowskiego na c.k Uniwersytecie we Lwowie). The development of Ciompa P. is a "classic representative" of scientific work and is known in historiography as "econometric balance theory". It was developed at the Lviv School of Commerce, and its theoretical and methodological level is evidenced by the fact that it was proposed for consideration at the next European Accounting Congress in Lyon (1914). This development takes the position that "intangible assets constitute capital only if the real effect of their productive force on the effective functioning of the economic entity, ie non-productive assets cease to be property of capital... capital disappears (undergoes reduction) and a former asset that has lost value for enterprises should not be counted on the balance sheet" [23, p. 13].

The problem of accounting for organizational funds (costs for the organization and formation of internally generated goodwill (business reputation)) also affected the issue (price) of shares, registration fees, and so on. In this context, discussions have unfolded regarding the write-off of their value (depreciation). There was an unequivocal position that since the acquired intangible assets (information, privileges, patents, etc.) are classified as property, plant and equipment, they should be depreciated in the same way as other property, plant and equipment. The depreciation of objects formed directly by the enterprise was approached differently: "in the case of founding and organizational funds it looks different than writing off the loss of share capital: they are value, represent the value of property and capital, and therefore can be indicated in the balance sheet as an asset" [23, p. 128].
The development of theoretical approaches was influenced by the requirements of regulatory policy in the financial sector. For example, the provisions of the Austrian legislation on the regulation of shares (\$21) allowed newly established insurance companies to "depreciate" (write off) organizational funds (up to 5 years) and final commission costs (up to 10 years). The balance not written off for the reporting period should be transferred to a new account as an asset. "This approach (reflected in the balance sheet of an unlisted intangible asset) was focused on future profits or one that could be offset by a third party in the sale of the business.

In the then regional financial and economic doctrines and accounting conventions (developments) the greatest controversy concerned the choice (selection) of means and methods of measuring such an abstract (without material content) category and to quantify the company has this kind of economic resources. Different approaches were proposed, but the common view was that by improving traditional approaches to the assessment of the intangible component of capital on the basis of existing methodological principles of accounting (metaphysical approach) is not able to solve existing problems. Analysis of the developed accounting developments of East Galician accountants of the studied period shows that their focus was on the formulation of new principles in the field of evaluation, rather than improving the methodological arsenal. The valuation of intangible assets should be approached differently than the valuation of tangible assets. Their real value lies in the income they can generate. The value of intangible property is its use, not its costs.

\section{Contents of topics related to intangible assets in the manuals $[31 ; 32]$}

\begin{tabular}{|l|l|}
\hline \multicolumn{1}{|c|}{ Góra W. Bilanse. Studja ekonomiki prywatnej (1920) } & \multicolumn{1}{|c|}{$\begin{array}{c}\text { Tomanek F. Ksiegowość kupiecka: } \\
\text { pojedyncza i podwójna (1923) }\end{array}$} \\
\hline $\begin{array}{l}\text { Analiza i krytyka bilansów (analysis and critique of } \\
\text { balance sheets) }\end{array}$ & $\begin{array}{l}\text { Konta składników majątkowych (paxyнки компо- } \\
\text { нентів власності) }\end{array}$ \\
\hline $\begin{array}{l}\text { - Stosunek wzajemny poszczególnych pasywów (the } \\
\text { relationship of individual liabilities) }\end{array}$ & $\begin{array}{l}\text { - Konta wkładek kapitałowych (capital contribution } \\
\text { accounts) }\end{array}$ \\
\hline $\begin{array}{l}\text { - Stosunek wzajemny poszczególnych aktywów (the } \\
\text { relationship of individual assets) }\end{array}$ & $\begin{array}{l}\text { - Księgowanie interesów partycypacyjnych (accounting } \\
\text { for interests with equity participation) }\end{array}$ \\
\hline $\begin{array}{l}\text { - Stosunek pomiędzy aktywami a pasywami bilansu (the } \\
\text { relationship between assets and liabilities) }\end{array}$ & $\begin{array}{l}\text { - Praktyczne zastosowanie księgowości w interesach } \\
\text { komisowych, partycypacyjnych i spółkach jawnych } \\
\text { (practical application of accounting in the interests of } \\
\text { commissions, joint and general partnerships) }\end{array}$ \\
\hline $\begin{array}{l}\text { - Analiza rachunku strat i zysków (analysis of the } \\
\text { income statement) }\end{array}$
\end{tabular}


Intangible values in the accounting theoretical and applied sphere of the Eastern Galicia of the second...

Under the influence of the above and many other theoretical developments in practice began a broad manipulation of the introduction into the balance sheet generalization of various types of "fictional" intangible value. This led to the bankruptcy of enterprises due to distortions in the share price and their real financial condition. The facts of real practice have naturally reduced the theoretical developments in the field of accounting for the intangible value of the enterprise. For example, the content of topics from later manuals Gora W. (1920) and Tomanek F. (1923). The first textbook was theoretical in nature and was intended for the studio study of the private economy, the second - was intended for higher trade schools and had a practical inclination, although the theoretical and scientific principles occupied a significant place in it.

The content reflected in these textbooks in comparison with the above shows a significant decrease in the amount of work in the field of accounting for intangible assets.

\section{Conclusion}

Based on the elaborated developments of East Galician scholars for the historical period defined by the article, it can be concluded that some justifications, which have been left out of the accounting of accounting, contain rational and for modern theory and practice elements of intangible assets. For example, the sound principle of "capital is written off" can be used to improve the existing standardization of goodwill accounting. Acquired goodwill is, in essence, the value of intangible assets not reflected in the balance sheet. Such an acquisition is usually made at the expense of the equity of the purchasing entity, and therefore the write-off of goodwill should be made at the expense of fixed capital and not attributable to costs. In a more precise version, it is a question of writing off at the expense of "reserve capital", which should be formed as a real source of financing in the structure of fixed capital. This becomes especially evident in crisis situations within the national or global economy. To create such targeted reserve capital requires stricter mandatory requirements at the state level. In the author's opinion, the strengthened regulations should be included in the international standard "Business Association"
The principles of writing off the value of intangible assets such as a trademark (trademark) proposed in the works of Western Ukrainian scholars - accountants at the turn of the era can also be used to develop a more objective conceptual basis for modern accounting of intangible assets. The content of the principles proposed at that time was the assertion of the illegality of using the methods of direct amortization of this group of intangible assets. The position was held that the productive power of this type of assets over time mostly only increases, and therefore used then and preserved to this day the approach of valley write-off of their value unreasonably distorts both the financial result and the book value of the enterprise. It was proposed that the company independently with the involvement of external experts to determine the list of objects, depreciation (write-off) of which is unreasonable from an economic point of view. Provisions of this nature in relation to this group of assets should be reflected in IFRS "Impairment of Assets". These proposals are based on those that will increase the level of objectivity of information about the intangible economic resources of modern companies.

\section{Reference}

1. IFRS 13 "Fair Value Measurement" (2013). Retrieved from: http//www.iasplus.com/en/ standards/ifrs/ifrs13.

2. Baruch, L. (2018). The deterioration usefulness of financial report information and how to reverse it. [Accounting and Business Research], 48, 5, 465493.

3. Koryagin, M. V., Kutsik P. O. (2016) Problemi ta perspektivi rozvitku bukhgalters'koï zvitnosti: monografiya [Problems and prospects for the development of accounting]. Kï̈v: Interservis [in Ukrainian].

4. Interconnected standard setting for corporate reporting. Accoutancy Europe's thoughtleadership series. - Brussels: Accountacy Europe, 2019. - 28 p.

5. Marr, B. (2007) Measuring and managing intangible value drivers. Business Strategy Series. Vol. 8, No. 3. P. 172-178.

6. Nazarenko, I. M. (2015) Rozvitok kategoriï "kapital": istorichniy diskurs $z$ pozitsiï oblikovogo aspektu [Development of the category "capital": historical discourse from the standpoint of accounting]. Naukoviy visnik Khersons' kogo derzhavnogo universitetu. Seriya: 


\section{O. Lemishovska}

Ekonomichni nauki. - Vip. 11. - S. 134-140. [in Ukrainian].

7. Rzhanitsyna, V. S. (2006) Buhgalterskiy uchet nematerial'nykh aktivov [Accounting for intangible assets: author]: avtoref. dis. ... kand. ekon. nauk: spets. 08.00.12 - bukhgalterskiy uchet, statistika // Sankt-Peterbuskiy gosudarstvennyy universitet [in Russian].

8. Kucher, S. V., Zakharov, D. M. (2017). Istoriya rozvitku gudvilu yak oblikovoï kategoriï ta osnovni pidkhodi do yogo viznachennya [The history of development of goodwill as an accouting category and the main approaches to its definition]. Ekonomika i suspil'stvo. - Vip. 9. 1162-1166.

9. Narisi ekonometrii i pobudovana na natsional' niy politekonomiï teoriya bukhgalters'kogo obliku (2001). [Essays on econometrics and the theory of accounting based on national political economy]. $L^{\prime}$ viv: Kamenyar, 2001. - 228 s. (Yaremko I. comment of the accounting aspect). - Lviv: Kamenyar. [in Ukrainian].

10. Yaremko, I. Y. (2009) Ideal' niy kapital [Ideal capital: copyright]: svidotstvo pro avtors'ke pravo № 7803 vid 18.06.2009 r./ Derzhavniy departament intelektual' noï vlasnosti Ministerstva osviti i nauki Ukraïni.

11. Pylypenko, L. M. (2016). Rozvytok kontseptsii pobudovy systemy publichnoi zvitnosti korporatsii $v$ umovakh postindustrialnoi ekonomiky [Development of concepts for building a system of public reporting of corporations in a postindustrial economy]. Lviv: Publishing House of Lviv Polytechnic National University [in Ukrainian].

12. Courtis, J. K. (1983). Business Goodwill: Conceptual Clari - fication via Accounting, Legal and Etymological Perspectives, The Accounting Historians Journal. Vol. 10, No. 2, p. 1.

13. Chatfield, M., R. Vangermeerseh. (2014). History of accounting: an international encyclopedia / Routledge.

14. Dicksee, L. R. (1897). Goodwill and its Treatment in Accounts // The Accountant, Vol. 23. No. 115 3, January 9.

15. Dicksee, L. R., Tillyard, F. (1906). Goodwill, Gee and Co., Printers and Publischers, Trind Edition, P. 33 .

16. Leake, P. D. (1921). Commercial goodwill: its History, Value and treatment in Accounts. London: Gee, 201p..

17. Hatfield, H. R. (1909). Modern Accounting, its principles and some of its problems. New York: D. Appleton.

18. Kaner H. A. New Theory of Goodwill. London: Sir I. Pitman \& Sons Ltd, 1937 Retrieved from: http//trove.nla.gov.au/work/13517505? q \& version $l d=16028315$.

19. Accounting Research Bulletin №-24 “Accounting for Intangible Assets" // Accounting Research Bulletins. - American Institute of Accountants. 1944. - P. 195-201.

20. Moralevych, Ya. (1924). Osnovy rakhunkoznavstva (lektsii na kooperatyvnykh kursakh ukrainskoi selo-spilky). Fundamentals of Accountancy (lectures on cooperative courses of the Ukrainian village-union). Terezyn: Pid zaradom upravy kursiv Ukrainskoi selianskoi spilky v Ch. - S. - R., 12 s.

21. Gorbachevskiy, V. (1946). Kurs buhgalteryi [Accounting course] [in Ukrainian].

22. Shumpeter, I. A. (2001). Istoriya economicheskogo analiza [History of Economic Analysis]. Avtonomowa [Edsi]. (Vols. 1-3). Moskow: Ekonomicheskaja shkola [in Russian].

23. Ciompa, P. (1910). Grundrisse einer öekonometrie und die auf der Nationalökonomie aufgebaute natürliche theorie der buchhaltung; ein auf Grund neuer ökonometrischer Gleichungen erbrachter Beweis, dass alle heutigen Bilanzen falsch dargestellt werden Verlag des Handelsschulvereines in Lemberg. Lemberg: Druck von Artur Goldman in Lemberg.

24. Stern, R. (1902). Buchhaltungs-Lexikon. Wien und Leipzig.

25. Reisch, R., Kreibig J. (1907, 1909). Bilanzund Steuer. I Band Wien, II Band Wien.

26. Simon, G. (1899). Di Bilalanzen der Uftigenfellitaften. German Veit Simon. Berlin.

27. Staub, Herman (1906): Kommentar zum Handels Gesetzbuch. 8. Auflage; Staub - Hachenburg (1913): Kommentar zum Gesetz, betreffend die Gesellschaften mit beschrankter Haftung. 4 Auflage.

28. Sher, I. F. (1925). Buhgalteriya i balans: per. $s$ nem [Accounting and balance] M.: Izd-vo “Ekonomicheskaya zhizn”. [in Russian].

29. Au, Juliusz. (1899). Nauka rachunkowosci dla potrzeb cospodarstwa wiejskiego zastosowanej. Lwow: I. Zwiazkowa drukarnja we Lwowe.

30. Sciborski, A. (1912). Podręcznik do nauki rachunkowości ogólnej i państwowej. Opracowany wedlug wykladów radcy Dworu Tadeusza KlusikOrzechowskiego na c.k Uniwersytecie we Lwowie: cześć I. Lwów: Drukarnja szcęsnego Bednarskiego we lwowie, nakladem wydawcy.

31. Góra, W. (1920). Bilanse. Studja ekonomiki prywatnej / Witołd Góra. Lwów - Warszawa: Książnica t-wa Nauczycieli szkót wyżsżych.

32. Tomanek, F. (1923). Ksiegowość kupiecka: pojedyncza i podwójna (z dołaczonemi wzorami 19 ksiag handlowych). Podręcznik dla szkót $i$ przedsiebiorstw handlowych. Odbito na papieerze w drukarni K. S. Jakubowskiego. wo Lwówie. 